\title{
Zerdüştîlik Yeniden Canlanıyor mu? (Kuzey Irak’ta Ortaya Çıkan Yeni Zerdüşsî Hareket Üzerine Bir Araștırma)
}

\section{Is Zoroastrianism Reviving Again? (A Study on the New Zoroastrian Movement in Northern Iraq)}

\author{
Mehmet Emin Sular ${ }^{\text {a,* }}$ \\ ${ }^{a}$ Dr. Öğr. Üyesi, Muş Alparslan Üniversitesi, İslami İlimler Fakültesi, Felsefe ve Din Bilimleri Bölümü, 49100, Muş/Türkiye. \\ ORCID: 0000-0002-4673-2544
}

\section{MAKALE BİLGİİ}

\section{Makale Geçmişi:}

Başvuru tarihi: 02 Kasım 2020

Düzeltme tarihi: 03 Şubat 2021

Kabul tarihi: 09 Şubat 2021

Anahtar Kelimeler:

Zerdüștîlik

Kuzey Irak

Pîr Lokman

Med

Yesna
ÖZ

20. yüzyıldan itibaren Celadet ve Kamuran Ali Bedirhan gibi seküler milliyetçi Kürt aydınlar, Kürtlerin Medlerden geldikleri, İslam öncesi dinlerinin Zerdüştîlik olduğunu iddia etmişlerdir. Bu iddialar gelişen Kürt milliyetçiliğine bağlı olarak Kürtler için şanlı tarih, kadîm bir din oluşturmayı amaçlamıştır. Söylemler zamanla, bazı okur-yazar kesim arasında da karşılık bulmuştur. 2012 yılında İsveç-Stockholm'da Andez Hawezi dine yeni giren taraftarlarıyla bir Zerdüştî tapınağ kurmuştur. Onun desteği ve yurt dışından dönenlerle Kuzey Irak'ta Zerdüştîliğe geçişte bir hareketlilik başlamıştır. 2014'te DEAŞ'ın saldırıları, geçişleri daha da hızlandırmış ve yeni bir Zerdüştî Hareket ortaya çıkmıştır.Yeni Zerdüştî Hareket, çıkışından kısa süre sonra Pîr Lokman ve Yesna Grubu şeklinde ikiye bölünmüştür. Çalışmanın amacı Yeni Zerdüştî Hareket hakkında bilgi verdikten sonra iki grubu ayrı ayrı incelemektir. Araştırma için alan çalışması yapılmış ayrıca yazılıgörsel veri sağlayan kitap, makale ve dijital kaynaklardan faydalanılmıştır.

\section{A R T I C LEINFO}

\section{Article history:}

Received 02 November 2020

Received in revised 03 February 2021

Accepted 09 February 2021

\section{Keywords:}

Zoroastrianism

North Irak

Pir Lokman

Med

Yasna

\begin{abstract}
A B S T R A C T
From the 20th century onwards, secular nationalist Kurdish intellectuals such as Celadat and Kamuran Ali Bedir Khan claimed that the Kurds came from the Medes and their pre-Islamic religions were Zoroastrianism. These allegations aimed to establish a glorious history and an ancient religion for the Kurds due to the development of Kurdish nationalism. Over time, some of the educated people have also responded to these discourses. Thus, in 2012 Andaz Hawezi established a Zoroastrian temple in Stockholm, Sweden with his newcomers to religion. Moreover, with his supports and those who returned from abroad, a movement began for the transition to Zoroastrianism in Northern Iraq. On the other hand, in 2014, ISIS attacks have accelerated the transition and a new Zoroastrian Movement has emerged. This New Zoroastrian Movement was divided into two groups as Pir Lokman and Yesna group shortly after its emergence. From this point of view, the aim of this study is to examine these two groups after giving information about the new Zoroastrian Movement. For the research part of this study, a field study was conducted and books, articles and internet which provide written and visual data were used.
\end{abstract}

\section{Giris}

Son zamanlarda Zerdüştîliğin yeniden canlandırılmasıyla ilgili birtakım girişimlerin olduğu görülmektedir. Toplumsal hayatta kişi veya kurum adı olarak Avesta, Zerdüşt ve Fraveher gibi bu dine ait birçok kavram ve sembolle karşılaşmaktayız. Zerdüştîliğe ait kitaplar yoğun ilgi görmektedir. Ayrıca Kürtlerle Zerdüştîlik arasında bağlantı kurularak Kürtlerin İslam'dan önce Zerdüştî oldukları (Xemgin, 2011: 223), Zerdüşt'ün Med devleti (M.Ö. 728559) döneminde yaşayan bir Kürt peygamber olduğu, isminin Kürt dilinden geldiği vb. iddialar bazı yazılı kaynaklarda s1kça geçmektedir (Bilgin, 2003: 121-122; Xemgin, 2011: 77-80; Cemilpaşa, 2018: 35; Foltz, 2017: 91).

\footnotetext{
* Sorumlu yazar/Corresponding author.

e-posta: meminsular65@hotmail.com
} 
İddialar özellikle Kürt milliyetçi seküler aydınlar tarafından dile getirilmektedir. ${ }^{1}$

Zerdüştîlik ile ilgili hareketlilik, Birinci ve (1990-1991) İkinci Körfez Savaşı (2003) neticesinde fiili olarak ortaya çıkan yarı özerk Kuzey Irak bölgesi için de söz konusu olmuştur. Burada yukarıda ifade edilen iddialar karşılık bulmuş; 2015 yılında yeni bir Zerdüştî Hareket ortaya çıkmıştır. Süleymaniye şehrinde şekillenen Hareket, Bölgesel Hükümet'in din işlerinin yürütüldüğü Vezâret-i Evkâf (Diyanet İşleri Başkanlığıyla eşdeğer) kurumunda resmi olarak temsil edilmektedir. 2015 y1lında tek merkezde çalışmalarına başlayan Hareket, günümüzde Süleymaniye'de biri resmi diğeri gayr-i resmi iki merkezde farklı iki grup şeklinde faaliyetlerini sürdürmektedir. Çalışmanın konusu Hareket' $i$ ele almadan önce konunun anlaşılması noktasında Bölge'nin siyasi ve toplumsal yapısı hakkında bilgi sahibi olmak önem arz etmektedir.

Kuzey Irak, Irak merkezi hükümetine bağlı yarı özerk bir yapı olmakla birlikte siyasal anlamda statüsü tartışmalıdır, gelecekte Bölge'yi bekleyen gelişme ve olayları şimdiden tahmin etmek zor görünmektedir. 5.2 milyon nüfusa sahip Bölge'de Asuri, Türkmen, Ermeni, Arap, Keldani, Yezidi, Ehl-i Hak/Kakai ${ }^{2}$ ve Kürt gibi farklı din, mezhep ve milletlerden insanlar yaşamaktadır. Nüfusun yüzde 80' nini Sünni Şafii Müslüman Kürtler oluşturmaktadır (KRG, 09/11/2019; Aziz, 2013: 36). Bölgedeki dinsel çeşitliliğe son dönemde Zerdüştîliğe girenler de ayrı bir grup olarak eklenebilir. Güney Irak ve Suriye'deki kargaşa ve dinsel şiddetten kaçan azınlıklar için Bölge bir kaçış merkezi haline gelmiş, bu da çeşitliliği artırmıştır.

Halk gerek Bölge'nin statüsündeki belirsizlikten kaynaklı gerekse geçmişten gelen birçok sorunla karşı karşıyadır. Bölge, 1992 yılından beri iktidar gücünü elinde bulunduran seküler ${ }^{3}$ ve siyasal etkinliği olmayan dini hareketlerin etkisi altındadır (Filiz, 2019: 14). İki aktör de siyasal partiler yoluyla faaliyetlerini yürütmektedir.

Bölge'de siyasi ve ekonomik güç, Birinci Körfez Savaşı öncesinde olduğu gibi sonrasında da patrimonyal eğilimli iki seküler parti arasında paylaşılmıştır. Bunlardan ilki ve en eskisi Barzani ailesinin liderliğini yürüttüğü Kürdistan Demokrat Partisi (KDP) diğeri Talabani ailesinin yönettiği Kürdistan Yurtseverler Birliği (KYB)dir (Aziz, 2013: 29). Günümüzde kendilerine ait silahlı güçleri olan iki parti, 1998'te imzalan Washington Antlaşması'yla Bölge'yi ortaklı bir idari sistemle yönetmektedirler (Aziz, 2013: 104130). Erbil-Duhok şehirlerinin yönetimi KDP'de Süleymaniye-Derbandikhan ise KYP'dedir.

KDP, 1946 yılında Kürt milliyetçiliği esas alınarak Bağdat'ta kurulur. Parti'nin başkanı Sovyetler Birliği'nde sürgünde olan Molla Mustafa Barzani seçilir. Pragmatik bir kişiliğe sahip olan Molla Mustafa Barzani, hareketinde ideolojik yaklaşımlar yerine kişiliğini ve başarısını ön planda

\footnotetext{
${ }^{1}$ Celadet ve Kamuran Ali Bedirhan kardeşler Suriye'de 1932-1943 yılları arasında çıkardıkları Hawar adlı dergide, Cigerxwin şiirlerinde, Ekrem Cemilpaşa, Sıraç Bilgin, E. Xemgin ve Cemşid Bender gibi yazarlar da kitaplarında bu iddiaları dile getirmișlerdir.

${ }^{2}$ Ehl-i Hak veya bölgede Kakai olarak bilinen heterodoks inanç, Şia karşıtı inançtan neşet eden Yezidiliğin aksine kökleri İslam öncesi geleneğe dayanmakla birlikte Şia mezhebi içinden ortaya çıkmıştır. İran sınırları içerisinde şekillenen inancın kutsal metinleri Gurani dilindedir. Ehl-i Hak sonradan Lur, Azeri Türkleri, Fars ve Türkmen gibi etnisiteler arasında da yayılmıştır. İnancın temeli birçok defa insan bedenine
}

tutar (Aziz, 2013: 104-105). Molla lakabını kullanmaktan çekinmeyecek kadar geleneksel değerlere bağlıdır. Buna rağmen İkinci Dünya Savaşı'ndan sonra Bölge'de sayıları artmaya başlayan sol-seküler kişi/grupların da partisine girmesine ve üst görevlere yükselmesine izin verir. Parti zit fikirde olanları bir araya getiren/birleştiren çatı işlevini görür. Fakat sol çevrelerin katılımıyla geleneksel dini yapısından sol-seküler bir çizgiye evrilir (Filiz, 2019: 79-80). 1975 yılında sol-seküler kanat, Irak-İran arasında yapılan Cezayir Antlaşması'nın Kürtler açısından ortaya çıkardığı kötü sonuçların nedenini KDP'ye bağlar ve tartışmalar sonucunda Celal Talabani önderliğinde ayrılarak KYB'yi kurar.

1979 yılında Molla Mustafa Barzani’nin ölümünden sonra oğlu Mesud Barzani yerine geçer (Filiz, 2019: 132). KDP'nin günümüzde milliyetçi, seküler, aşiret sistemine bağlı fakat geleneksel değerlere karşı tavır almada ürkek ve pragmatik bir siyaset yürüttüğü söylenebilir. Bir yanda geleneksel değerlere bağlılık bağlamında camiler inşa edip İslami faaliyetleri desteklerken diğer taraftan yeni Zerdüştî Hareket ve 2015 yilında kurulan siyasi ve seküler Dabıran Hareketi'ne destek verebilmektedir (Filiz, 2019: 178-179). Hatta KDP'ye bağlı bazı radikal Selefi gruplar bulunmaktadır (Filiz, 2019: 102).

Genç kentli kesim tarafindan destek gören KYB'nin ise milliyetçi, sol ve devrimci bir parti olarak çizgisi daha nettir (Filiz, 2019: 136). Dini oluşum ve faaliyetlere mesafelidir; ideolojisi doğrultusundaki hareketlere arka çıkmaktadır. 2009 yılında KYB'den ayrılan daha özgürlükçü ve liberal Goran Hareketi'nin de seküler partiler bağlamında ismi belirtilmelidir. Bölge'de halk nezdinde karşılığı az olan başka küçük partiler de bulunmaktadır (Filiz, 2019: 7).

Hem Barzani hem Talabani aileleri günümüzdeki siyasiseküler duruşlarına rağmen dini bir geçmişe sahiptirler. Barzani Nakşibendi, Talabani ailesi Kadiri tarikatlarına mensup şeyh aileleridir. İki tarikatın bölgedeki faaliyetleri devam etmektedir (Bruinessen, 1991: 11-12). Daha önce dini kimliği ön planda olan ailelerin şartların değişmesiyle politik/siyasi bir yapıya kavuşarak hareketlere yön verdikleri görülmektedir.

Yönetimde seküler partilerin bulunması ve bu yönde siyaset geliştirmelerine rağmen halkın genelinin Müslüman olduğu bir yerde İslami partilerin çıkmaması düşünülemez. Bir ideoloji, din ve hareketin karşıtını oluşturması ve ortaya çıkarması genel bir durumdur. Bu bağlamda Kürdistan Íslami Hareket, Kürdistan İtihad-l İslam Partisi ve Kürdistan Cemaat-l İslami Partisi başlıca dini partilerdir. İslam Devrimi'nden sonra İran'ın Bölge'de İslamî kurumlar oluşturma teşebbüslerine rağmen İslamcı hareket, ideoloji ve partilerin halk arasında dikkati çekecek düzeyde ilgi gördüğü söylenemez (Bruinessen, 1991: 17).

girdiğine inanılan Tanrı ve onun farklı yönlerini temsil eden altı/yedi baș melek inancına dayanır. Tanrı'nın bedenine girdiği kişilerden biri Hz. Ali'dir. Ali'yle ilgili benzer inancı Ğulat-ı Şia, Nusayriler de paylaşır. Ehl-i Hak'ka göre Tanrı'nın en büyük enkarnasyonu Ali'yle değil grubun kurucusu Sultan Sahak ile gerçekleşmiştir (Bruinessen, (1991), 7-8.

${ }^{3}$ Devlet ile dinin birbirinden ayrılması ilkesi olarak anlaşılan sekülarizm, ulus-devlet inşa etme konusuyla yakın ilişkili bir kavram olup yasaları insanların düzenlemesi gerektiğini ve halk egemenliğini esas alır (Göle, 2017: 15). 
Seküler ve İslami partiler dine yaklaşım ve hedefledikleri toplum modelinin farklı olmasına rağmen bağımsız bir devlete götürecek Kürt milliyetçiliği ve modern bir Kürt ulusu yaratma düşüncesinde ortak idealler paylaştıkları ifade edilebilir. Etnik-ulus yaratmak için de bazı araçlar gereklidir. $\mathrm{Bu}$ araçlar ya toplum içinde mevcuttur ya da bazen icat edilir. Ortak kültür, paylaşılan tarih, coğrafya, mitler, gelenekler, ulusal öz, bayrak, milli marş, dil, halkın ruhu, folkloru ve din bu araçlardandır (Aziz, 2013: 26).

Bölge'de seküler kesimin inanca dair ana vurgusu tarihte Kürtlerin dini olduğunu iddia ettiği Zerdüştîlik üzerinedir. Bunlar açısından köklerini Zerdüştîlik’ten aldığını söyledikleri Yezidilik de ayrı bir öneme sahiptir. İslam'ı da Kürtlerin ulus aşamasına geçememesin sebebi olarak görürler. İslamcı partiler ise ulus kimliği yaratma sürecinde İslam'ı alır ve onu Kürt kimliğinin ayrılmaz parçası kabul ederler (Filiz, 2019: 70-71). Sekülerler kesime göre Bölge'deki farklı din ve mezhepteki insanlar için İslam ve İslamcılar büyük tehlike arz etmektedir (Filiz, 2019: 186187). Ancak sekülarizm ile farklı din ve kültürlerin bir arada yaşaması mümkün görülürken teokratik bir yönetimde bunun mümkün olmayacağı ifade edilmek istenmektedir.

Bölgesel Hükümet'teki partiler, Bölge'nin seküler, milliyetçi karakter kazanıp siyasi İslami bir yapıdan uzaklaşması için çaba içerisinde oldukları söylenebilir. ${ }^{4} \mathrm{Bu}$ amaçla söylemlerini destekleyecek hareket ve oluşumlara direk veya dolaylı destek verirler. Resmi olarak 2015 yılında açılışı onaylanan yeni Zerdüştî Hareket bu kapsamda değerlendirilebilir. Çalışmanın amacı Hareket'i, onu ortaya çıkaran etkenleri, mevcut dini ve siyasi yapısını incelemektir. İlk olarak Hareket hakkında genel bilgiler verilecek sonra Yesna Grubu ve Pîr Lokman Grubu ayrı ayrı ele alınacaktır. Araştırma için Ağustos-2019 tarihinde alan çalışması yapılmış ayrıca yazılı-görsel veri sağlayan kitap, makale ve dijital kaynaklardan faydalanılmıştır. Alan çalışmasında kendileri ile görüşme gerçekleştirilen kişilerden izin alınanlar gerçek isimleri, alınamayanlar ise müstear isimle belirtilmiştir.

\section{Yeni Zerdüştî Hareket}

Zerdüştîliğe yeniden dönüş hareketi entelektüel temelini, 20. yüzyıl boyunca gelişen seküler Kürt milliyetçiliğine borçludur. Aslında Kürtler arasında atalarının Zerdüştî oldukları veya Zerdüştîlikle ilişkili geleneklere inandığı yönündeki bilgi, yirminci yüzyıl öncesine dayanmaktadır. Fakat fikrin gelişmesi, Kürtlerin kökeni, kültürü ve milliyetçi söylemin bir özelliğine dönüşmeye başlaması 20. yüzyılda gerçekleşmiştir (Barber, 2019: 230). Bu konuda öne çıkan iki etkin kişi Celadet ve Kamuran Ali Bedirhan kardeşlerdir. Bedirhan kardeşler, 1932'den 1943 yılına kadar Suriye'de çıkardıkları Hawar adlı dergide Kürtlerin kökeninin Medlere dayandığı, İslam'dan önceki dinlerinin Zerdüştîlik olduğunu iddia etmiş; Kürt kimliğinin kültürel parçası gördükleri Zerdüştîliğe özel ilgi göstermişlerdir (Bedirhan, 1932: 37 38). İddiaları sonradan Cigerxwin, M. Sıraç Bilgin, E. Xemgin ve Cemşid Bender gibi Kürt sol milliyetçi

\footnotetext{
4 Onların çalışması karşılık bulmuş gibidir. 2007 yılında Bölge'de 376 üniversite öğrencisiyle yapılan ankette, öğrencilerin yüzde 83,6 gibi yüksek oranda İslam'ın bölge halkı birliğini sağlamada önemli olmadığını öncelikli olanın etnisite olduğunu belirtmişlerdir. Sonuç İslam'ın genç eğitimli kesimin düşüncesinde ve ulus kimliği inşa etme sürecinde fazla yer tutmadığını göstermektedir (Aziz, 2013: 187-188).
}

entelektüeller tarafindan kabul görmüş, yazılıp çizilmiştir. Bazı milliyetçi aydınlar da Zerdüştîlik’ten gelen kökleriyle Yezidiliği mükemmel bir Kürt dini görmüştür. (Bruinessen, 1991: 1).

1990 yılından itibaren bu fikirler somutlaşmış, başta Avrupa olmak üzere Irak ve İran gibi yerlerde bireysel olarak Zerdüştîliğe geçişlerle ilgili haberler duyulmaya başlanmıştır. 2000 yılında itibaren ise din değiştirmeler daha organizeli bir boyut kazanmıştır (Barber, 2019: 229). 2012'de yoğun Kürt nüfusunun yaşadığı İsveçStockholm'da Andez Hawezi denilen kişi tarafından ilk Zerdüştî tapınağı açılmıştır. Amaçlarının Zerdüştîliği yeniden canlandırma olduğunu ve şu an İsveç'te 3 binden fazla Zerdüştî olduğunu belirten Hawezi, ${ }^{5}$ Kuzey Irak'ta Zerdüştî Hareket'in ilham kaynağı olmuştur. Bununla kalmamış iki grup için dini bir lider ve akıl hocası olarak önemli bir pozisyondadır; iki merkezde de fotoğrafı asılıdır. ${ }^{6}$

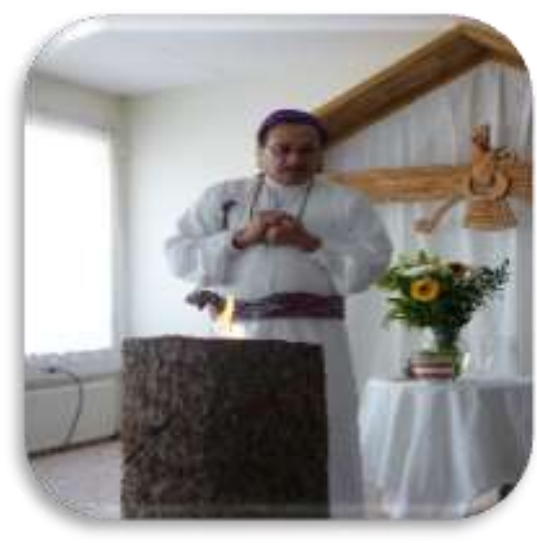

Fotoğraf 1. Andez Hawezi. (RG, 09.01.2012).

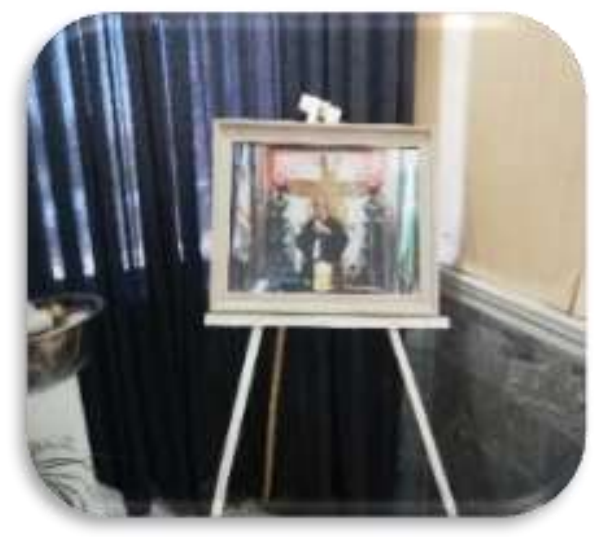

Fotoğraf 2. Andez Hawezi'nin Pîr Lokman Grubu'nun merkezindeki fotoğrafi (M. Emin Sular, 29/08/2019).

Kuzey Irak'ta Hawezi'nin desteği ve Avrupa'dan Bölge'ye dönenlerle Zerdüştîliğe geçişler ivme kazanmıştır. Hareket resmiyet kazanmadan önce Duhok, Zaho gibi şehirlerde din değiştirip aile ve çevrelerinden gizleyenler olduğu ifade edilmiştir (Szanto, 2018: 98-99; Smith\&Shadarevian, 2016: 19). Mart 2015 yılında da Zerdüştî dinin tanıtma ve yayılma görevini organizeli yürütecek Zerdüştî Yüksek Meclisi resmi

\footnotetext{
$\left.{ }^{5} \mathrm{WZO}, 28 / 02 / 2012\right)$.

${ }^{6}$ Hareket için önemli diğer bir kişi İranlı Şii olup sonradan Zerdüștîliğe geçen ve ABD'de yaşayan Ali Ekber Caferi'dir. Zerdüştîlik hakkında çok sayıda çalışması olan Caferi'nin, Zerdüşt'ün hayatını anlatan kitabı, Takûr adındaki kişi tarafından Farsçadan Sorancaya tercüme edilmiştir.
} 
olarak açılmıştır. Kurucu başkanı sonraları Pîr Lokman adıyla meşhur olacak Lokman Hacıkerim olmuştur (Albayan, 12/12/2019). Hareket'in İslam, Hıristiyanlık ve Yahudilik gibi resmiyet kazanması ve kabul görmesi yerel hükümetin dini azınlıklara haklarının verilmesine yönelik çıkardığı kanunun 5. maddesiyle mümkün olmuştur (A Reading for the Law of Protecting Components in Kurdistan, 5. Mad. 2015). Yeni Zerdüştî Hareket'e, Bölgesel Hükümet'in din işlerini yürüten Vezâret-i Evkâf kurumunda dört yılda bir seçimle değișmesi hükme bağlanan bir temsilci bulundurma hakkı tanınmıştır. Ellili yaşlardaki Awat Husameddin, temsilci olarak seçilmiştir. Kısaca Awat olarak tanınan kadının Vezâret-i Evkâf’taki görevi devam etmektedir. $^{7}$

Yasal olarak tanınmak Zerdüştîliğe geçenlere kurumsal yapılarını oluşturma ve toplumda kabul edilebilme açısından önemli bir katkı sağladığı söylenebilir. Fakat ortada hala bir belirsizlik ve handikap vardır. Çünkü Bölge'nin bağlı olduğu Irak yasaları, İslam hukukunu esas aldığından İslam'a girişlere izin vermekte fakat dinden çıkmaları zımnen yasaklamaktadır (Civil Status Law 17 of 1972; Smith\&Shadarevian, 2016: 19). Dinden çıkış bir yana Müslüman bir kadının Ehl-i Kitap'tan bir erkekle evlenmesine dahi izin vermemektedir (Personal Status Law 17 of 1959; Barber, 2019: 234). 18. maddede Müslüman olmayanların evliliğinde, eşlerden birinin İslam'a girmesi halinde ne olacağı açıklanmaktadır. Böyle bir durumda şeriat kurallarına göre hükmedileceği, eğer İslam'a giren erkekse evliliğini devam edeceği, kadınsa evliliğin feshedileceği anlatılmaktadır (Personal Status Law 18 of 1959).

Resmi tanınmadan sonra 1 Mayıs 2015 tarihinde Pîr Lokman önderliğinde Zend denilen grup tarafından Süleymaniye şehrine yakın bir köyde, ilk dine giriş/Sudrepûşî töreni ${ }^{8}$ yapılır. Törenle çok sayıda kişi Zerdüştîliğe geçer ve beline dine girişi sembolize eden kuştî ipini bağlar. Özellikle 2014 yılında DEAŞ’ın Bölge'ye yönelik saldırıları Zerdüştîliğe geçişleri hızlandırır. Hükümetten alınan izinle 22 Eylül 2016 tarihinde Süleymani'ye şehrinde ilk tapınak/ateşkede açılır (Foltz, 2017: 96-97). Aynı yıl içerisinde Pîr Lokman gruptan ayrılır kendisine bağlı olanlarla yeni bir tapınak/merkez kurar. Bu sebeple Süleymaniye'de şu an iki ayrı Zerdüştî grup bulunmaktadır. Yesna resmidir ve Vezâret-i Evkaf'ta temsilci bulundurma hakkı vardır. Pîr Lokman Grubu ise resmi onayı olmamakla birlikte faaliyetlerini sürdürmektedir. Dönemin Vezâret-i Evkaf'ın başkanı Merivan Nakşibendî, Pîr Lokman'ın resmi onay almadan yer kiralamak suretiyle bir oluşum başlattığını buna rağmen bu merkeze gelenlerin ibadetlerini yapmakta özgür olduğunu belirtmektedir (IRNA, 22/09/2016).

Hareketin bölünmesiyle ilgili birkaç neden zikredilebilir. Bunların başında kişisel hırs ve rekabet gelmektedir. Pîr Lokman, İran ve Hindistan'da Zerdüştî din adamlarından ders almış iyi derecede Farsça bilmektedir. Zerdüştîler arasında kalmış onların ritüelleri nasıl yaptıklarını ve geleneklerini çok iyi öğrenmiştir. Bunun yanında öne çıkan,

\footnotetext{
${ }^{7}$ Zerdüştîliğe yeni girenlerle bölge hükümeti arasındaki koordinasyon Awat tarafından sağlanmaktadır. Awat'a iletilen talepler yetkililere ulaștırılır.

${ }^{8}$ Bazı dinlerde, dine girme ve dinin emirlerini yerine getirme sorumluluğ belirli yaşta kendiliğinden gerçekleşirken Yahudilik ve Zerdüştîlik gibi dinlerde ise bu ancak bir tören ile gerçekleșir. Zerdüștîlikte Sudrepûșî olarak isimlendirilen törenle akıl baliğ olan çocuk dine girmiş olur. Din adamı yönetiminde yapılan törende, çocuk sudre denilen beyaz yakasız gömleği giyer, beline de kuştî ipini bağlar. Bununla rızasıyla dine girmiş
}

hırslı, aşırı kibirli kişiliğiyle Pîr Lokman kendisini bölgedeki tüm Zerdüştîlerin dini temsilcisi olarak nitelemekte ve bunu açıkça söylemektedir. Baskın kişiliğiyle Yesna'da aradığını bulamayan Pîr Lokman, Awat ile sorunlar yaşadığından yeni bir oluşuma gitmiştir.

İkinci önemli neden siyasidir. Siyasi gücü elinde bulunduran KDP ve KYP Bölge'yi ikiye bölmüştür. İki partinin kendisine ait hakimiyet alanı, toplumsal hayatta arkasında durduğu kurumlar vardır. Bir hareketin Bölge'deki parçalı siyasi güçten kaynaklı bölünmesi doğaldır. Yerel kıyafetler giyip yerelliğe vurgu yapan Pîr Lokman Grubu KDP, Yesna ise KYP'ye yakın görünmektedir.

Dini açıdan iki Zerdüştî grup arasında önemli farklar olmamakla birlikte ilişkilerinin iyi olduğu söylenemez. İki taraf birbirine yönelik suçlayıcı dil kullanır ve kendisini gerçek diğerini yapay, siyasi ve bireysel çıkarlarını önceleyen bir hareket olarak nitelendirir.

İki grup da kendilerini tanıtma, anlatma konusunda çok isteklidirler. Günlük faaliyetlerini canlı olarak yayınlarlar. Ulusal ve uluslararası medyaya bilgi verirler. Dışarıdan gelen araştırmacı ve ziyaretçilere merkezlerini gösterir ve gezdirirler. Çekime gelen bir televizyon kanalı için göstermelik dini ve evlilik törenleri yaparlar (Szanto, 2018: 102-103). Bazı konularla ilgili görüşlerini ortaya koyan kısa tanıtım videoları hazırlarlar. 1437 Yll Sonra'da cinsel ahlak, sonraki video filminde DEAŞ yüzünden Müslüman Kürtlerin İslam'dan ayrıldığı ele alınmıştır (Szanto, 2018: 107-108).

\subsection{Zerdüştîliğe Geçenlerin Sayıs1, Kimliği ve Din Değiştirmelerin Temel Sebepleri}

Alanda gerçekleştirilen çalışmada Zerdüştîliğe geçenlerin sayısı hakkında kesin verilere ulaşılamamıştır. Konuyla ilgili soru yöneltilen Awat, net bir sayı vermekten kaçınarak sayılarının yüz binleri aştığını, her gün farklı yaş gruplarından kadın-erkek Müslüman, Hıristiyan, Arap ve Yezidi'nin törenle kendilerine katıldığını ayrıca dine girdiğini gizleyen çok sayıda kişi olduğunu belirtmiştir. (Awat Husameddin, Görüşme, 29/08/2019). ${ }^{9}$ Pîr Lokman da her gün onlarca kişinin kendilerine geldiğini söyleyerek buna yakın bir cevap vermiştir. İki grubun temsilcisinin sayılarını fazla gösterme noktasında gayret içinde olduğu ve verilen rakamların abartılı olduğu söylenebilir. Çünkü iki merkezde çarşamba günleri halka yönelik verilen seminere (onlar dini tören diyor) veya önceden düzenlenmiş bazı bayram kutlamalarının internetteki görüntülerine bakıldığında katılımcıların onlarca kişiden oluştuğu görülmektedir. Eğer ifade edildiği üzere hareketin içindekiler çok olsaydı seminer veya bayram kutlamalarının çok daha kalabalık olması gerekirdi. Katılımcıların hepsinin din değiștirdiği de söylenemez. Çünkü Hareket'e ilgisi sempati düzeyinde olanlar ve devlet görevlileri de aktivitelere katılabilmektedirler. Her türlü programa Awat'la birlikte katılan elli beş yaşlarındaki Zerdüştî eși, yalnız olduğumuz

ve dini emirleri yerine getirme sorumluluğunu kabul etmiştir (Nîknâm, 1388/2009: 46-47), Yahudilik'te ise erkekler için 13 yașında Bar Mitzva kızlar için 12 yaşında Bat Mitzva denilen tören düzenlenir. Bununla erkek-kız dinin emirlerini yerine getirmekle yükümlü olurlar (Alalu vd., 2001, 88-89).

9 Awat, bu yönde soru soran araştırmacı ve haber ajanslarına genelde sayılarının 100.000 dolayında olduğunu belirtmektedir (Smith\&Shadarevian, 2016: 19). 
sırada Süleymaniye'de 1-2 bin civarında dine girenin olduğunu ifade ederek daha gerçekçi bir sayı belirtti (Cemal Husameddin, Görüşme, 27/08/2019). Hükümet yetkileri de ellerinde bölgede Zerdüştîliğe girenler hakkında kesin bir rakamın bulunmadığını ifade etmekle birlikte yüzlerle ifade edilen sayısal değerlerden bahsetmektedirler (IRNA, 22/09/2016). Sonuç olarak sayı vermek gerekirse yüzlerle ifade edilecek bir rakam karşımıza çıkmaktadır. Bölge'de özellikle farklı yerlerde ikamet edip iletişim içinde olan okur-yazar kesimden Hareket'e karşı ilgi bulunmaktadır. Fakat ilginin katılıma dönüşerek büyük sayılara ulaştığı söylenemez. ${ }^{10}$

Bölge'de Zerdüştîliğe geçen veya ilgi duyan orta-üst tabakadan Kürt milliyetçileri genelde Marksist görüşlerden derin şekilde etkilenen kişilerdir. Bunlar için Zerdüştîlik öğrenilecek ve yaşanılacak biri dini gelenek yerine, gerçekleştirmek istedikleri siyasi emelleri uğruna kültürel bir sembol, İslam'a alternatif ahlaki bir oluşum, Kürt halkının özelliklerini taşıyan bir gemi ve temel karakterini tanımlayan değerdir. Bu grupta Zerdüştîliği otantik tanımlayıcı bir kimlik kabul eden agnostikler hatta ateistler vardır. Bunun yanında Zerdüştîliği bir din olarak gören ve öğrenmek isteyen az kişiden de bahsedilebilir. İki yaklaşımın ortak yönü milliyetçilik ve Zerdüştîliğin İslam'a alternatif bir din görülmesidir (Barber 2019: 230-231; Foltz, 2017: 97).

Yesna Grubu'nda Zerdüştîliğin dinden ziyade ahlaki kurallar bileşkesi ve felsefe olduğu vurgusu hemen göze çarpar. Buna göre din değiştiren kişi sadece ahlaki kuralları dikkate almalıdır. Pîr Lokman Grubu'nda ise din ve ritüel vurgusu daha fazladır. Pîr Lokman ibadetlerde Avesta'dan ezberlediği bazı metinleri okur. O ayrıca yeni bir Zerdüştîlik icat etmediklerini atalarının uyguladığ 1 şekilde milli dinlerini yaşamak istediklerini belirtir (Pîr Lokman, Görüşme, 30/08/2019).

Yeni Zerdüştî Hareket'e katılanlarının genelinin geleneksel Müslüman bir aileye mensup oldukları fakat İslam'a karşı aidiyet ve bağlarının zayıf olduğu anlaşılmıştır. 2014 yılındaki DEAŞ saldırısı ve Ortadoğu'daki diğer radikal örgütlerin şiddet eylemleri, İslam'ın imajına oldukça zarar vermiştir. Birçok kişi tamamen dinden uzaklaşarak ateist olurken bazısı da din değiştirmeyi tercih etmiştir. Bunların yönleri genelde İslam öncesi Kürt dini olduğunu iddia ettikleri Zerdüştîliğe doğru olmuştur. Bunun yanında Hıristiyanlığa girenlerden de bahsedilmektedir (Galletti, 2016: 163; Smith\&Shadarevian, 2016: 19). Din değiştirenlerle gerçekleştirilen görüşmelerde İslam'ın şiddet ve öldürmeyi emrettiği, farklı din ve kültürlere yaşam hakkı vermediği vurgusu ön plana çıkmaktadır. Bunlardan biri yetmiş yaşlarındaki emekli, beş çocuk babası Muhammed Hamit Süleymani'dir. Önceden Müslüman olan Süleymani, 2006'da Mormonluğ'a, ${ }^{11} 2017$ y1lında ise tekrar din değiştirerek Zerdüştîliğe geçmiştir. Şu an ateşkededeki

\footnotetext{
${ }^{10} 2012$ yılına kadar farklı ülkelerde bulunan Zerdüștîlerin sayılarının tespiti için yapılan çalışmalarda, Irak'ın listeye dahil edilmesini gerektirecek sayıda Zerdüştî olmadığ 1 görülmektedir. Günümüzde ise yeni dine girenlerle sayının yüzlerle ifade edilecek orana ulaşması dikkat çekicidir (FEZANA, 01/02/2021).

${ }_{11}$ Mormonluk, 1805 yılında doğan Joseph Smith ve arkadaşları tarafindan kurulan bir harekettir. Smith, Moroni denilen meleğin kendisine Mormon Kitabı'nı yazılı olduğu altın levhaları indirdiğini iddia etmiștir. Hareketin içindekiler Smith önderliğinde Ahir Zaman Azizleri İsa Mesih Kilisesi'ni Utah'ta kurmuşlardır. Günümüzde sayılarının 50 milyon olduğu tahmin edilen taraftarlarının yüzde sekseni Amerika'da bulunmaktadır. Mormon öğretisinin dayandığı bazı prensipler Hıristiyan iman doktrininden
}

uygulama ve törenlerde giydiği beyaz elbiselerle aktif bir rol üstlenmektedir. Süleymani'nin din değiştirmesinin sebebi belirttiğine göre bazı örgütlerin şiddet eylemleridir. Çocuklarının ve eşinin dinin ne olduğu sorusuna: "Onlar DEAŞ'lı” şeklinde cevap vererek İslam'a bakışını ortaya koymuştur. Ona göre İslam, başka din ve kültürlerdeki insanlara dine girme, cizye/vergi ödeme veya öldürülme seçeneklerini sunmuştur. Ayrıca kadını, erkekten aşağı görmüş, ona yeterince hak tanımamıştır. Aklı reddeden gerici bir dindir. ${ }^{12}$ Zerdüştîlik ise sevgiyi, barışı, ilerlemeyi, söz, düşünce ve eylemde doğru ve medeni olmayı emretmiştir. Özgürlüğü önemsemiş, kadın-erkeği eşit görmüş, öldürmeyi yasaklamış ve tabiatın korunmasını esas almıştır. Kimseye din seçme ve ibadet yapma dayatmasında bulunmamıştır (Muhammed Hamit Süleymani, Görüşme, 29/08/2019). İran vatandaşı olup siyasi nedenlerden kaçak yolla Kuzey Irak’a geçerek oturma izni almaya çalışan kırk beș yaşlarındaki Sünni bir aileye mensup $\mathrm{Azad}^{13}$ ve üniversite öğrencisi Diyako, Zerdüştîliğe geçişlerini aynı nedenlere dayandırmışlardır. Diyako, durumunu zarar göreceği endişesiyle çevresinden sakladığını, ayrıca Hareket'i siyasi görüşlerine yakın gördüğünden buna katıldığını ifade etmiştir (Diyako, Görüşme, 29/08/2019).

Din değiştirmelere diğer bir etken İslam'la özdeşleşen Araplara yönelik antipatidir. İddiaya göre Araplar, İslam'a girdikten sonra Kürtlere İslam'1 kabul ettirmek için baskı yapmış kabul etmeyenleri öldürmüşlerdir. $\mathrm{Bu}$ bağlamda İslam'dan ayrılarak Zerdüştîliğe geçmek baskıya, Araplara ve İslam'a başkaldırıyı temsil etmektedir (Szanto, 2018: 100). İslam ve Araplara yönelik bu yaklaşımın sebeplerinden biri yüzbinlerce kişiyi öldüren ve binlerce yerleşim alanını yok eden Bölge'ye yönelik Saddam Hüseyin'in düzenlediği Enfal ve Halepçe saldırıları olduğu söylenebilir. Yakın dönemde gerçekleşen bu trajik saldırıların hatıraları insanların zihninde canlılığını korumaktadır. Saddam bir Arap-Müslümand,, her ne kadar seküler olsa da yeri geldiğinde dini argümanlar kullanmıştır.

Milliyetçilik, Arap ve İslam düşmanlığ̣ vurgusu din değiştirenlerin konuştukları dilde de kendini göstermektedir. Bu kişiler konuşmalarında Arapça ve İslami kelimeler yerine Kürtçe olanları kullanmaya çalışırlar. Selamlaşmada halk arasında yaygın olan selamun aleykum yerine aynı anlamı ifade eden âşiti kelimesini kullanırlar. Tu hayır hati (hoş geldiniz) deki Arapça hayır kelimesinden dolayı fir hati tabirini tercih ederler.

\subsection{Hareket'in Müslüman Halk ve Bölgesel Hükümetle İlişkileri}

Bölge insanın genelinin-günlük beş vakit namaz ve oruç gibi İslami ritüelleri yerine getirmese de- inancı güçlüdür; giyimkuşam, yiyecek, içki ve sünnet gibi konularda dini emirlere uyarlar. Bundan dolayı Süleymaniye'deki insanların, yeni

ayrılmaktadır. Bunlardan bazıları şöyledir: Mormonlar, 1- Çok tanrılığa açık kapı bırakmışlardır. 2- Tanrı'nın insandan türediğine ve insanın tanrılaşabileceğine inanmışlardır. 3-Teslisi oluşturan unsurların ayrı varlıklar oldukları ve insanların ruhlarının ezelden beri var olduğunu kabul etmişlerdir... (Aydın, 2005: 517-520).

12 Pîr Lokman'a göre, İslam kadını ikinci sınıf görmüștür. Cok eșle evliliğe izin vermiş ve ona örtünmeyi dayatmıştır. DEAŞ’ın Yezidi kadınları kaçırması, suiistimal etmesi ve köleleştirmesi İslam'dan kaynaklanmıştır (Szanto, 2018: 100).

${ }^{13}$ Eşiyle birlikte Süleymaniye'ye gelen Azad, Zerdüştîliğe geçişi halinde ikamet iznini almasının daha kolay olacağını söylemiştir (Azad, Görüşme, 28/08/2019). 
Zerdüştî Hareket'i desteklediği hatta ondan haberdar olduğu söylenemez. Şehirde iki Zerdüştî merkeze gitmek için yerini sorduğumuz kitap satıcısı, üniversite öğrencisi ve birçok taksiciden bilmedikleri yönünde cevap aldık.

İslami cemaatler ise din değiştirmeleri özellikle Zerdüştiliğe geçişleri olumlu görmemektedirler. Zaman zaman Hareket'e karşı bireysel tepkilerini ifade eden din adamı ve İslami kanaat önderleri ortaya çıkmaktadır. Bu durum Zerdüştîliğe geçenleri tedirgin etmekte ve baskı altında tutmaktadır. 2016 y1lında Selefi görüşlü Molla Abdullatif Ahmet, Zerdüştîliğe geçenlerin kınanması çağrısı yapmıştır. Pîr Lokman çağrıyı kendilerinin öldürülmesine yönelik bir işaret olarak yorumlamış ve dini radikalizmden tedirgin olduklarını ifade etmiştir (Foltz, 2017: 98; Albayan, 17/07/2016). ${ }^{14}$ Molla Ahmet eleştirilerini daha da ileri götürmüş Zerdüştîlerin anne ve kız kardeşleriyle evlendiklerini tarihten örnekler vererek belirtmiştir (Szanto, 2018: 107). Bazı radikal gruplar, din değiştirmeyi suç ve hainlik olarak kabul etmektedir (Smith\&Shadarevian, 2016: 20).

İki gruptan kişilerle yapılan görüşmelerde halkla ilişkilerde problemler ve gerginlik olduğu hissedilmektedir. İnternette iki merkeze dair fazlaca bilgi verilmemiş ve adreslerinin yazılmamış olması endişe ve korkunun yansıması olarak değerlendirilebilir. Buna rağmen iki gruba ait merkez binalarının önünde hükümete ait veya özel herhangi bir güvenlik önlemi yoktur. Kuzey Irak'ta faal kiliselerin önünde sürekli nöbet bekleyen hükümete ait güvenlik görevleri olduğu belirtilmelidir.

İki Zerdüştî grubun lideri pozisyonundaki Awat ve Pîr Lokman, 1srarla siyasi bir hareket olmadiklarını, siyasi faaliyetler yürütmediklerini, hiçbir yerden maddi destek almadıklarını ve gizli bir gündemlerinin olmadığını belirtirler (KP, 19/11/2019). Fakat faaliyet yürüttükleri bina, çalışanların masrafı ve yapılan uygulamaların büyük ve sürekli maddi kaynak gerektirdiği açıktır. Pîr Lokman, gelirlerinin cemaatindeki zenginlerin bağışlarından geldiğini söylemektedir (Pîr Lokman, Görüşme, 30/08/2019). Fakat maddi desteğin büyük oranda yerel hükümette iktidardaki KDP ve KYP'den gelmektedir. ${ }^{15}$ İki taraftan kişilerle yapılan görüşmelerde karşı tarafin hangi siyasi güç tarafından desteklendiği dile getirilmektedir. KDP, yapı olarak yerelliğe vurgu yapan Pîr Lokman'1, KYP'nin seküler Yesna grubunu desteklediği anlaşılmaktadır. Bölge konjonktüründe siyasi /ilişki/onay olmadan bir hareketin ayakta kalması mümkün görünmemektedir. Dolayısıyla ne kadar inkâr edilse de Hareket'in siyasetle ilişkili olduğu ve maddi destek aldığını söylemek yanlış olmaz.

Özellikle KDP bir strateji olarak bölgede önemli dini topluluklara, kabile, sivil önderlere ve eğitimli kişilerden seçtiklerine parti maaşı olarak bilinen ödemeyi yapar. $\mathrm{Bu}$ durum Huristiyan, Yezidi ve Zerdüştî gibi dini gruplar açısından birçok olumsuz sonuç ortaya çıkarmaktadır. Siyasetten uzak kalmak isteyen dini azınlıklar bununla patron-eleman ilişkisinde olduğu gibi patrona sadakat gösterme mecburiyetinde kalmaktadır. Dini kesimin ileri

\footnotetext{
14 Bölge'de son dönemde artan dini radikalizmden tüm dini azınlıklar da endişe etmekte ve uzun vadede bunun kendilerini tehdit edeceğine inanmaktadırlar. Ekonomik belirsizlik, siyasi durgunluk ve genç nüfusun fazlalığı dinsel radikalizmi besleyen başlıca sebepler olarak sayılabilir (Smith\&Shadarevian, 2016: 1).

15 Yesna'da aktif olarak çalışan İbrahim, Pîr Lokman'ın KDP'den destek gördüğünü ifade etmiştir (İbrahim, Görüşme, 29/08/2019).
}

gelen kişilerinden biri, maaş almayı kabul ettiğinde KDP'nin dini azınlıklara zarar verse dahi her türlü politikasını kabul etmek ve onaylamak zorundadır. Hükümetin parayla aldığ sadakat kendisine yönelik eleştirilerin önünü keser. Dini azınlıkların doğal gelişim seyri de bundan zarar görür. Cemaat üyeleri tarafından belirlenmesi gereken önderler, siyasetin tercih ettiği kişiler arasından çıkar. Bu durum siyasi ve dini liderlik şeklinde çift başlılık ortaya çıkararak cemaat arasında gerginlik meydana getirir. Vezâret-i Evkaf'a seçilen temsilciler dini azınlı ile hükümet arasındaki koordinasyonu sağlar. Siyasi onay olmadan hiçbir dini aktivite yapılamaz ve yapı inşa edilemez. Böylece her şey tamamen siyasete bağlanır. Hükümet grup içinde onaylamadığı hiziplerin çıkmasını engelleyerek dine müdahale eder. Yeni Zerdüştî Hareket'te farklı gruplar olmakla birlikte KDP ve KYP tarafindan kuruluş döneminde desteklenen ve Vezâret-i Evkaf'ta temsilci bulundurma hakkı verilen yalnızca Yesna'dır. Yesna'nın yaptığı her türlü işlem kolayca onay alırken diğer grupların faaliyetleri engellenir. 2016 yılında Erbil'de açılışının üzerinde dört ay geçen ateşkede kapatılmıştır. Fakat Yesna'nın Süleymaniye'deki merkezinin açılmasına kolayca izin verilmiştir (Barber, 2019: 232-233; Hanna ve Barber, 2017: $35)$.

\subsection{Hareket'in İran-Hindistan Zerdüştîleriyle İlişkileri}

Zerdüştîlik evrensel bir din olup, dışarıdan katılımlara açıktır. Fakat misyoner karakterli değildir. İran, Hindistan ve Batı'daki Zerdüştîler dinlerini yayma konusunda sistematik misyonerlik faaliyetleri yürütmezler. Dine dışarıdan kendiliğinden bir katılım söz konusu olursa bunu da olumlu karşılarlar (Sular, 2019: 94-96). Bunun yanında Hindistan'daki bazı dindar Parsîlerin/Zerdüştîlerin dine sonradan girişleri hoş görmedikleri belirtilmektedir (Foltz, 2017: 96).

Awat ve Pîr Lokman'a İran ve Hindistan'daki (Hindistan'dakiler Parsî olarak isimlendirilmektedir) Zerdüştîlerle ilişkilerinin nasıl olduğu sorulduğunda aralarında problem olmadığını, ilişkilerinin iyi olduğunu, kongre benzeri faaliyetlerde bir araya geldiklerini söylerler. Fakat dini konularda bilgi alışverişi yapmadıklarını, onların Fars/Pers Zerdüştîsi, kendilerinin Med Devleti ${ }^{16}$ Zerdüştîleri olduklarını ifade ederler. Özellikle Pîr Lokman sonradan anlatılacağ1 üzere Fars Zerdüştîleriyle aralarında yirmiye yakın farkın olduğunu belirtir. İki merkezde ateşkede olarak kullanılan yerlerin fiziksel yapısı, din adamlarının kıyafet şekli, bazı dini törenlerin yapılışındaki farklılık buradaki Zerdüştîliğin, kadîm Fars/Pers Zerdüştîliğinden çok ayrı olduğunu doğrulamaktadır. İki grubun yeni dini anlayışı tarihi arka plandan, dini hukuk kurallarından ve kutsal metinlerden yoksun yapay bir görünüm arz etmektedir. Sadece Zerdüştîlikten alınan iyi düşünce, iyi söz ve iyi eylemden oluşan üç temel ahlaki kuraldır. Her ne kadar adı Zerdüştîlik olsa da din adına söylenen ve yapılanların bölgeye özel, siyasi, milliyetçi, modern, liberal ve yapay bir görünüm arz ettiğini söylemek yanlış olmaz. Ortada
16 Med Devleti’nin resmi dinin Zerdüştîlik olduğuna dair kesin bir veri
bulunmamaktadır. Herodotos Medler'in altı boydan oluştuğunu
yazmaktadır. Bu boylardan biri, Zerdüştîlikle ilişkisi olduğu tahmin
edilen mag/muğlarlardır. Bu durumda dahi Zerdüştîliğin bu dönemde
halkın değil sınırlı bir azınlığın dini olduğu anlaşılmaktadır. Halkın
genelinin güneş ve ay gibi tabiat olaylarına taptığı belirtilmektedir
(Herodotos, 2013: 59; Sular, 2019: 27-28; Guillemin, 1385/2006: 203). 
kendisinden bahsedilen bir din var fakat dinin kendisinin olduğu söylenemez.

\section{Yesna Grubu}

Yesna, Süleymaniye şehir merkezinde KYB parti binasına yakın iki katlı çok amaçlı bir binada faaliyet yürütmektedir. Katlardaki odalar özel amaçlar için düzenlemiştir. Merkez, dini yerden ziyade bir kültür merkezini andırmaktadır. Alt kattaki odalardan biri, program veya tören öncesi gelenler için bekleme yeridir. Yaklaşık kırk metre kare büyüklüğünde diğer bir oda mabet/ateşkede olarak kullanılmaktadır. Mabet daha çok bir kilise ve konferans salonunu andırır. Arka tarafa sandalyeler öne de bir sahne konulmuştur. Sahnede bir masa, arkasında Bölgesel Hükümet'in bayrağı, tahtadan büyükçe bir Zerdüştî fraveher sembolü̈ ${ }^{17}$ vardır. Masanın hemen yanına sadece törenlerde yakılan gazlı ocak yerleştirilmiştir. Duvarlarda da Zerdüşt ve dine ait çok sayıda sembolün resmi asilıdir.

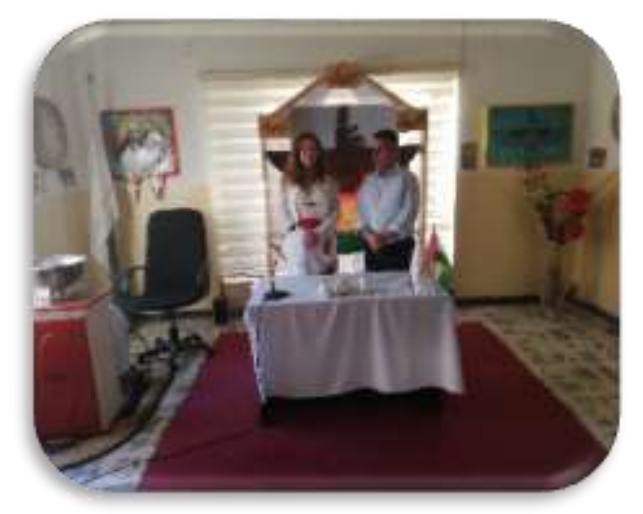

Fotoğraf 3. Yesna merkezindeki mabet. (M. Emin Sular, 28/08/2019)

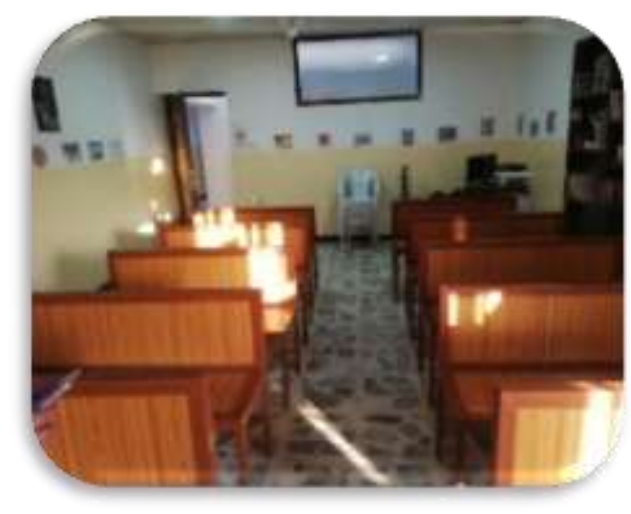

Fotoğraf 4. Yesna merkezindeki mabet. (M. Emin Sular, 28/08/2019)

İkinci katta Righeravi-yi Med (Med Kurumu) ve Turî Pikhâtı Ayını $\hat{u}$ Netevakâni (Farklı Din ve Milletlerden Insanları Birleştirme Merkezi) adında iki kurum bulunmaktadır. Righeravi-yi Med, farklı ülkelerden Süleymaniye şehrine gelenlere iş bulma ve maddi destek sağlamakla görevlidir. Turî Pikhâtı Ayını û Netevakâni de farklı dinlerdeki insanların bir araya geldikleri merkezdir. Bu kurumlara ait tabelalar binanın dış duvarına monte edilmiştir.

\footnotetext{
${ }^{17}$ Fraveher sembolünde, süslü elbise giymiş yaşlı bir adam, başında külahla doğuya doğru başı dik şekilde ayakta durur. Duruşuyla neşe ve kuvvetle kanatlarını açmış uçuşa hazır kuşu andırır. Yaşlı adam, bir halkanın içinden geçer, sağ eliyle dua eder, sol elinde küçük bir halka tutar. Sembolün üzerindeki her işaret, ahlâkî açıdan ulaşılması gereken hedefe ișaret eder (Sular, 2019: 73; Hurş̂̀dyan, 1387/2008: 394-395).
}

Yesna'da din adamı için asrevan ${ }^{18}$ ismi kullanılmakta ve ikisi erkek, biri kadın toplamda üç asrevan görev yapmaktadır. Asrevanların fotoğrafları mabette duvara asılıdır. Bir kişinin nasıl din adamı olduğu sorusuna Awat, kendilerinde asrevan, môbed ve môbed-i môbedan ${ }^{19}$ şeklinde hiyerarși olduğunu ve Hawezi'nin din adamı olacak kişiyi belirlediğini ifade etmiştir (Awat Husameddin, Görüşme, 29/08/2019). Erkek asrevanlardan biri Suriyeli ellili yaşlardaki Esaam, diğeri sosyal medya hesaplarında Asrevan Kadrok adını kullanan altmış yaşlarındaki kişidir. Dini törenler özellikle Asrevan Kadrok tarafından düzenlenir. Kadın asrevan Awat, resmi görevinin yanında hareketin medya yüzüdür. İngilizce, Arapçayı iyi derecede bilen Awat, her türlü televizyon programına çıkar ve yabancı medyayla röportaj1 gerçekleştirir.

Sakalsız erkek asrevanlar, yerel kıyafetlerden izler taşıyan beyaz ve kırımızı renklerden oluşan bir üniforma giyerler. Kiyafet kombinasyonu beyaz, yakalı ve uzun kollu bir gömlek, beyaz şalvar, ayakkabı ve çoraptan oluşur. Başta kırmızı külah, belde üç defa sarılarak önden üç düğüm atılmış pıştbend denilen kırmızı kuşak olur. Küçük madeni bir fravher sembolü takılı kırmızı boncuklardan oluşan kolye de boyuna takılır. Kadın asrevanın kıyafeti, boyun bölgesi açık ayaklara kadar uzanan beyaz bir fistan ve bele bağlanan kırmızı bir kuşaktır. Başta herhangi bir örtü yoktur.

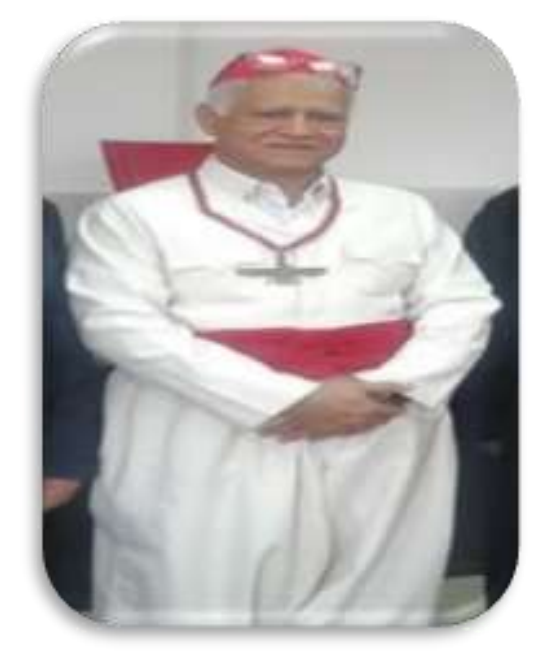

Fotoğraf 5. Dini kıyafetleriyle Asrewan Kadrok. (Asrevan Kadrok'un facebook hesabından alınmıştır)

\footnotetext{
${ }^{18}$ Asrevan veya atrabân, Avesta ve Veda metinlerinde din adamları için kullanılan en eski isimdir. Asrevan'ın Ârilerde ateşi sürekli besleyerek yanar vaziyette tutan kişi olduğu sonradan dini bir özellik kazanarak Avesta metinlerine geçtiği belirtilmektedir (Sular, 2019: 165; Moayyerî, 1381/2002: 23-25).

${ }^{19}$ Günümüzde İran Zerdüştîlerinde hîrbed-môbed, destûr şeklinde bir din sinıflandırması vardır (Sular, 2019: 173-174).
} 


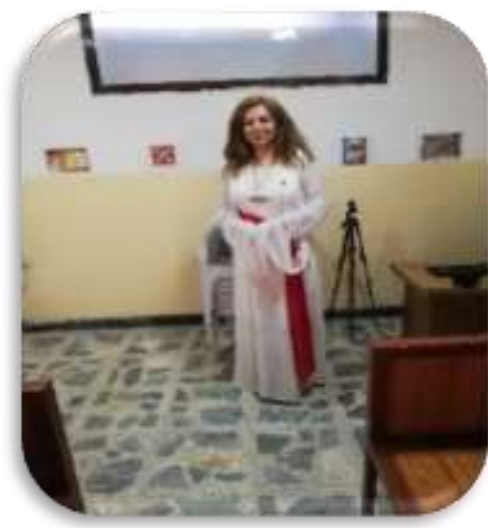

Fotoğraf 6. Dini kıyafetleriyle Awat Hüsamettin. (M. Emin Sular, 28/08/2019)

Asrevanların kıyafetleri, İran'da môbed denilen Zerdüştî din adamlarından bazı yönlerden farklılık arz etmektedir. Môbedlerin kıyafetleri beyazdır, kombinasyonda kırmızı renkli hiçbir parça yoktur. Şalvar yerine pantolon söz konusudur, gömlek de üstte dizlere kadar uzanır. Kadın môbedlerin başı örtülüdür ve el-yüz hariç boyun bölgeleri dahil vücutları tamamen kapalıdır (Sular, 2019: 177-178).

Asrevanların gömleği, sudre; pıştbendinin ise kuştî olduğu belirtilmektedir. İran Zerdüştîleri elbisenin altında sudre denilen beyaz yakasız, önde ve arkada cepleri olan bir gömlek giyerler. Sudrenin üstüne de yetmiş iki iplikten oluşan kuştî ipini bağlarlar. İp bele üç defa dolanır, önde iki arkada iki düğüm atılır. Sudre giymek ve kuştî bağlamak Ahûramazda'ya bağlılığı sembolize eder ve her Zerdüştî için farzdır. (Sular, 2019: 273). Yeni Zerdüştî Hareket'in kadîm Zerdüştî inancına ait en temel araç ve kavramları kendilerine göre yeniden isimlendirdikleri, şekillendirdikleri ve anlamlar yükledikleri görülmektedir.

Yesna Grubu, semitik dinlerin haftanın bir gününü kutsal kabul etme inancına benzer çarşamba gününü kutsal, önemli bir gün olarak belirlemiştir. Her çarşamba Zerdüştîlik hakkında çalışmaları olan dışarıdan getirilen biri tarafından mabette konferans düzenlenir ve canlı olarak yayınlanır. Neden çarşamba, günün hangi özelliğinden dolayı seçildiği sorulan asrevan Esaam, kesin sebebini bilmediğini fakat büyük ihtimalle bunun Yezidilik'ten kaynaklanmış olabileceğini belirtmiştir (Esaam, Görüşme, 28/08/2019). Yezidiler çarşambayı kutsal gün kabul eder, miladi takvime göre on üç nisandan sonraki çarşambada büyük önem verdikleri Çarşema Sor bayramını kutlarlar (Suvari, 2013: 52-53; Lescot, 2009, 63). Yeni Zerdüştî Hareket'in bölgede Yezidilik ve Yezidilerle olan yakınlıkları/ilișkileri göz önüne alındığında böyle bir etkileşimin olma ihtimali yüksek görünmektedir.

Kadîm Zerdüştîliğin takviminde haftalık bölümlenme olmadığından Zerdüştîlerde bir haftada belirlenmiş özel, kutsal bir gün yoktur. Bu konuda da bir farklılaşma olduğu görülmektedir.

Alan araștırması boyunca bir dine giriș töreni ve konferans hariç mabette namaz ve dua benzeri bir ibadetin yapıldığı tespit edilmemiştir. Zerdüştîlikte adı namaz olup günde beş vakit yapılması gereken ibadet vardır (Âferin, 1393/2014:

${ }^{20}$ Rus arkeolog Diakonov Kızkapan mezarlığının Med kralı Cyarex'in (M.Ö. 625-585) ait olduğunu iddia etmiştir. Fakat bu bilgi doğrulanmış
12-13). İran Zerdüştîleri günün belirli vakitlerinde mabede gider Avesta okur, dua eder ve namaz k1larlar. Oruç ve kutsal yerleri ziyaretle ilgili de ortada bir faaliyet söz konusu değildir. Ritüeller konusunda kadîm Zerdüștî inanciyla büyük ayrışma bulunmaktadır.

Zerdüştîlikte yedi ile on beş arasındaki tüm erkek-kız çocukları için Sudrepûşî denilen dine giriş töreni düzenlenir. Törenle çocuklar dini kabul eder ve ibadetleri yapmaya mükellef olurlar. Günümüzde İran'da Sudrepûşî anne-baba ve akrabaların katılımıyla büyük bir coşkuyla yapılır. Yaklaşık iki saat süren törenden sonra dine kabul edilen çocuklara belge ve hediyeler verilir. (Sular, 2019: 274-279). Yesna Grubu'nda ise isteyenler için dine giriş töreni düzenlenir. Tören genelde gizli yapılır, dışarıdan kayıt alınmasına izin verilmez. Fakat adayın isteğine bağlı olarak bu değişebilir. Ortalama beş dakika süren törende, beyaz kıyafetler giymiş ve başında beyaz külah olan adaya, iki din adamı tarafından beyaz bir kuşak bağlanır. Aday, tören boyunca Sorani diliyle din adamının söylediklerini tekrar eder. Sonra ateşin karşısında dua eder ve tören biter. Asrevanlar mabette haftada on-onbeş kişi için dine giriş töreni düzenlendiğini belirtirler.

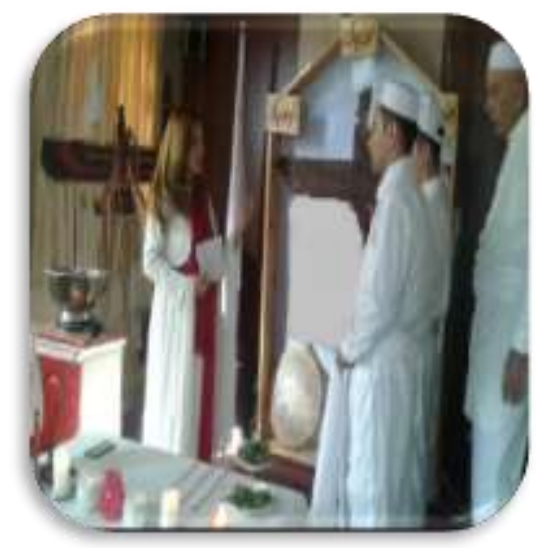

Fotoğraf 7. İki kişi için yapılan dine giriş töreni. (Asrevan Kadrok'un facebook hesabından alınmıştır)

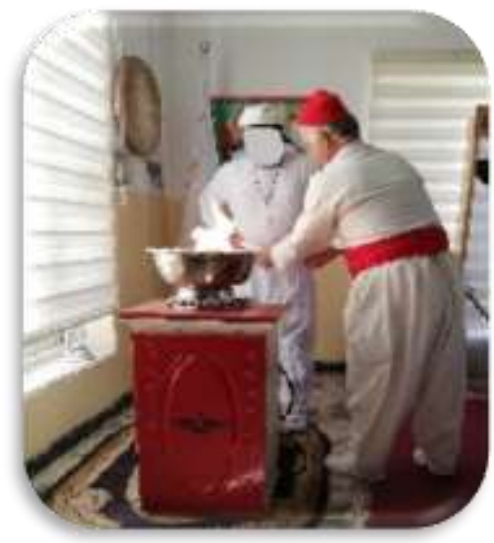

Fotoğraf 8. Tören sonrası ateşin karşısında dua etme. (M. Emin Sular, 29/08/2019)

Yesna Grubu bazı törenlerini Kızkapan'da yapar. Kızkapan, Süleymaniye şehrinin 70 kilometre kuzeyinde yer alan dağa oyulmuş bir mezardır. Med dönemine ait olduğu belirtilen Kızkapan, yeni Zerdüştî Hareket'in ideolojisinin/inancının kutsal hac merkezi konumundadır. ${ }^{20}$ 


\section{Pîr Lokman Grubu}

Grup, önceden ifade edildiği üzere asıl adı Lokman Hacıkerim fakat kendisini kısaca Pôr Lokman olarak tanıtan kişi tarafından kurulmuştur. Bedenen zayıf, 1.70 boylarında ve minyon tipli Pîr Lokman, evli ve üç çocuk babasıdır. İran'da Zerdüşti din adamlarının yanında beş, Hindistan'da ise bir buçuk yıl dini eğitim görmüştür. Din adamı olma belgesini Fransa'da yaşayan İranlı Zerdüştî din adamı ve yazar Kurûş Nîknâm'dan 2013 yılında almıştır. İsteyenlere belgeyi gururla göstermektedir. Bazı dini konulara hâkim olan Pîr Lokman, kutsal olduğunu söylediği görevine kendini vakfettiğini, devletten veya başka bir yerde maaş almadığını, geçimini de dışarıda yaptığı başka işlerle sağladığını belirtmektedir. Ailesi İngiltere'de olan Pîr Lokman, yılın belirli zamanlarında Süleymaniye'ye gelmektedir.

Grup, şehrin işlek ve lüks bir mahallinde üç katlı bir binada faaliyet yürütmektedir. İlk kat karşılama salonudur. Ziyaretçiler sekreter tarafından karşılanıp deftere kayıt edildikten sonra orta kata çıkarlar. İkinci katta mabet olarak kullanılan oda ve büyükçe bir mutfak yer alır. Mabette dikkati çeken, önde 1şıklandırılmış tahtadan büyük fraveher ve onun üstünde asılı olan taştan güneş sembolüdür. Mabet'te Zerdüştî tapınaklara özel sürekli yanan bir ateş yoktur. Bunun yerine ateş için iki gazlı lüküs ve mumlar kullanılmaktadır. Kilimle serili odada ayrıca iki kanepe ve birkaç sandalye bulunmaktadır. Üçüncü katta da farklı amaçlar için kullanılan dört oda yer alır. Odalar toplantı yeri, misafirhane ve okuma yeri olarak dizayn edilmiştir. Dördüncü oda stüdyoya dönüştürülmüştür. Merkezde her ne kadar Yesna'ya göre dini hava/ortam daha fazla olsa da siyasi ve kültürel görüntü ağırlıktır.

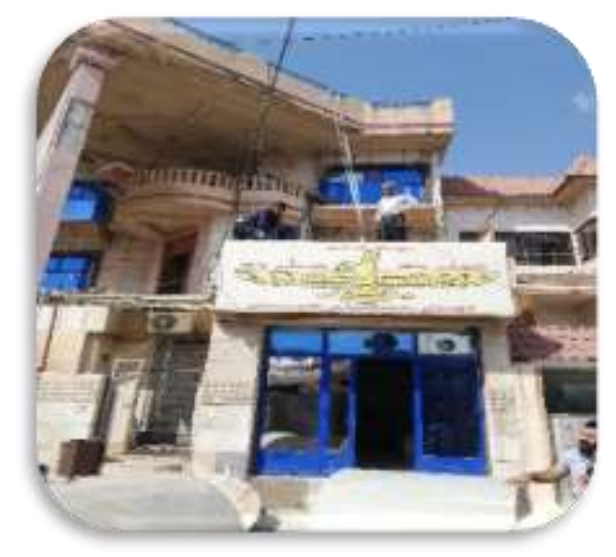

Fotoğraf 9. Pîr Lokman Grubu'nun merkezi. (M. Emin Sular 29/08/2019)

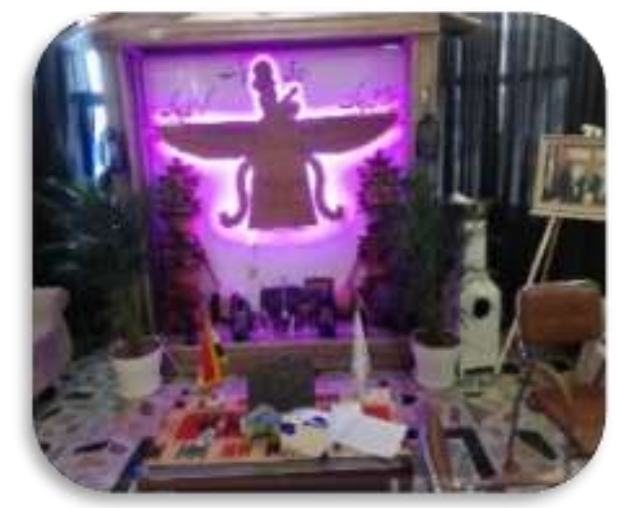

Fotoğraf 10. Pîr Lokman Grubu'nun mabedi. (M. Emin Sular 29/08/2019)

Binada dini faaliyetler dışında, müzik ve sanatla ilgili dersler verilmekte ve okuma etkinlikleri düzenlenmektedir. Bu faaliyetlerle çocuk-gençlerin merkeze gelmeleri ve burasının onlar için bir cazibe merkezi olması hedeflendiği ifade edilebilir.

Merkezde dinle ilgili bütün altyapı ve belirlemeler Pîr Lokman tarafından yapılır. Din adamı için pîr ismi kullanılan grupta din adamlarına yönelik pîr-pîrşalyar-mezmuğan şeklinde hiyerarşi belirlenmiştir. Pîr Lokman kendisinin hem pîr hem de bir üst derece olan pîrşalyar olduğunu söylemektedir. Mabette biri kadın dördü erkek beş pîr görev yapmaktadır. Pîr ismi büyük ihtimalle Yezidilik'ten gelmiştir. $^{21}$

Pîrlerin kıyafet şekilleri yereldir ve yakın zamana kadar bölge halkının geneli tarafından kullanılırdı. Başta renkli bir külah veya sarık olur. Uzun kollu beyaz bir gömlek, üstüne gri kolsuz cepli yelek ve altta geniş gri şalvar vardır.

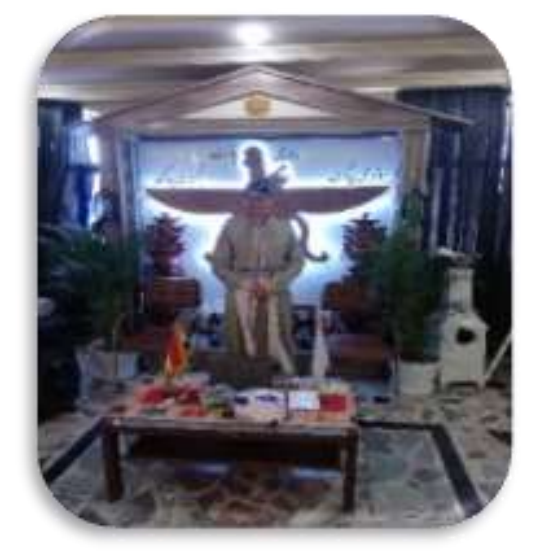

Fotoğraf 11. Dini kıyafetleriyle Pîr Lokman. (M. Emin Sular, 29/08/2019) din adamı, bir ateş altarı ve fraveher rölyefi yer alır. Perslerde fraveher sembolünde çift kanat vardır. Buradaki dört kanatlıdır. Mezarın kesin olarak kime ve hangi döneme ait olduğu bilgisi henüz netlik kazanmış değildir. Buna rağmen Kızkapan bir grup tarafından ideolojilerini/inançlarını destekleyici bir yer/unsur olarak görülmektedir (Foltz, 2017: 100; AO, 29/11/2019).

${ }^{21}$ Pîr, Yezidilik'teki kast sisteminde şeyhlerden sonra gelen önemli bir dini sınıftır. Şeyh Adi'nin ilk Kürt müritlerinin soyundan gelen dört ana klana ait yaklaşık iki yüz pîr ailesi vardır. Laliş tapınağına bekçilik yapmak pîrlerin en seçkin görevleridir. Bu yüzden onlara baba çavuş adı verilmiştir. Hiç evlenmemeleri gerekir. Dini törenlere pîrler şeyhlerle birlikte katılır ama idari görevlere karıșmazlar. Zamanlarını tefekkür ve ibadetle geçirirler. Şeyhlikte olduğu gibi pîrlik de babadan oğula geçer (Guest, 2007: 73; Bruinessen, 1991: 5. 


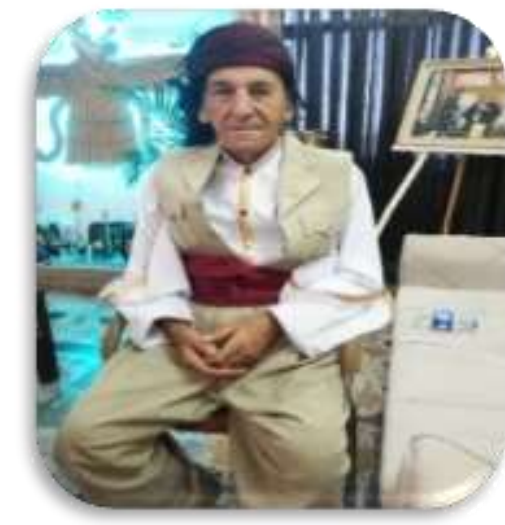

Fotoğraf 12. Dini kiyafetleriyle Pîr Kamil. (M. Emin Sular, 29/08/2019)

Pîr Lokman Grubu da kutsal gün olarak roja jiyanı (hayat günü) olarak isimlendirdiği çarşambayı kabul etmiştir. Buna bağlı olarak her yıl Bölge'de Yezidilere özgü Çarşema Sor bayramını da kutlamaktadır. Pîr Lokman ayrıca günlük beş vakit namaz, nebûr ${ }^{22}$ ve bayram kutlamaları benzeri tüm ritüelleri yaptıklarını belirtmektedir. Namaz ibadetinde Pir Lokman ayakta durur ellerini dua pozisyonunda açarak Hord Avesta'dan Avestaî Dil'le ezberlediği bazı bölümleri okur. Karşısında da ellerini açan cemaatten kişiler durur ve Pîr'in söylediklerini tekrar ederler. Ortamda bulunan erkekkadınlardan biri havana benzeyen zili çalar. Yaklaşık iki dakika süren uygulama bir namaz sayılır. Namazdan önce Zerdüştîlikte el ve yüzün yıkanması şeklindeki zorunlu temizliğe riayet edildiği söylenemez. İbadetin Pîr Lokman'ın bildiğini (bazı pasajları ezberlemiş) söylediği Avestaî Dil'le yapılması dikkati çekmektedir. İran Zerdüştîlerinin namaz kılma şekli bundan farklıdır. Onlar duruma göre ateş, güneş veya ayın karşısında durur Hord Avesta'dan bölümler okurlar. Bu arada kuştîlerini söker tekrar bağlarlar. Daha uzun süren namazda zil veya benzeri bir alet de çalmazlar. (Sular, 2019:187-191).

Pîr Lokman, hareketlerinin özgün, İran ve Hindistan'daki Zerdüştîlikten bağımsız olduğunu özellikle vurgulamaktadır. Aralarında maddeler halinde şu farklar olduğunu belirtmektedir:

1- En başta Tanrı anlayışımız farklıdır. Onlar her şeyin yaratıcısı Ahûramazda'ya inanırlar. Biz evrenin büyük patlama neticesinde kendiliğinden oluştuğuna inanırız. Tanrı da kendini yaratmıştır.

2- Zerdüştîlere göre Avesta Tanrı'nın yazılı olarak gönderdiği bir kitaptır. Halbuki bize göre Tanrı hiçbir yazılı metin göndermez. Aksi halde Tanrı'nın somut karşılığı olması gerekir. Tanrı mesaj gönderir, insanlar yazıya geçirir.

3- Onların Avestası beş, bizimki dört bölümden oluşur. Biz Avesta'ya Ahameniş dönemi Fars kültür, gelenek ve hukuk kurallarını içeren Vendidâd'ı dahil etmeyiz. Pîr

${ }^{22}$ Nebûr, Zerdüştîlik’te ayın belirli dört gününde kesilen hayvan etinin yenilmemesi şeklinde yapılan bir ibadettir. Bir çeşit perhiz olan nebûr kısmen oruca benzediği söylenebilir.

${ }^{23}$ Önceden ifade edildiği üzer Med vurgusu Awat tarafından da yapılmıştı. Süleymaniye'de Awatın, Med Resturan ' $l$ adında bir ticari ișletmesi vardır.

${ }^{24}$ Zerdüștîler ateși kutsal kabul ettiklerinden mabetlerinde odun, çıra ve mum benzeri araçlarla sürekli yanan ateş bulundururlar. Ateşin olmadığı durumlarda onun ișlevini elektrikli bir ampul görür. Mabede geldiklerinde ateşe yönelir dua, ibadet eder ve Avesta okurlar. Zerdüştîlerin bazı önemli
Lokman, İran Zerdüştîlerinde olmayıp Hindistan'dan getirdiğini söylediği kutsal Giyuş adlı gizli bir kitaptan bahsetmektedir.

4- Bele bağladığımız kuşak kuştî, kollu yakalı beyaz gömlek de sudremizdir. Din adamı kıyafet şeklimiz Medlerden kalma gri renkli yerel motifler taşır. Zerdüştîlerin kuştîsi, 72 iplikten oluşmakta, sudreleri yakasız kolsuz gömlektir; din adamlarının kıyafeti de beyazdır.

5- Zerdüşt bir Kürt'tü. Biz onun gerçek torunlarıyız Farslar değil.

6- Fars Zerdüştîlerinde din adamı olmak için belirli bir soydan gelmek gerekir ve kadın da din adamı olamaz olsa bile regl döneminde törenleri yönetemez. Halbuki bizde soyuna bakmaksızın erkek-kadın herkes din adamı olabilir ve her zaman dini törenleri düzenleyebilir.

7- Onlarda çocukların dine giriş yaşı 7'dir, bizde ise 12'dir.

8- İran ve Hindistan'da bir Zerdüștî ancak kendi dininden biriyle evlenebilir. Bizde cemaatten biri başka dinden istediği kişiyle evlenmekte özgürdür.

9- Tarihteki referans noktamız Med Zerdüştîliğii'dir;23 onlarınki Ahameniş Zerdiştîliği'dir.

10- Bizde isteyen gelir dine katılabilir biz evrenseliz. Halbuki İran Zerdüştîleri dışarıdan katılımları hoş görmez, Fars milliyetçiliğini savunurlar.

11- Bizim Behrâm ${ }^{24}$ denilen sürekli yanan kutsal bir ateşimiz yok, ateşi sadece Nevrûz'da yakarız. Ateş olarak mum ve elektrikli 1şık kaynağı kullanırız. Zerdüştîlerin sürekli yanan kutsal bir ateşleri var ve her tören, uygulamalarında ateş yakarlar.

12- Zerdüştîler biri öldüğünde mezarına gül suyu, biz şarap dökeriz.

13- Onlarda eyûkzen evliliğinde kız çocuğu mirastan pay almaz. Halbuki bizde her durumda k1z evlat mirastan erkekle eşit haklara sahiptir.

14- İranlı Zerdüştîler Şahnâme’yi okur ve önemserler. Biz bu kitaba önem vermeyiz ve okumayı.

15- Zerdüştîler, ölümden sonra cennet-cehennem denilen ruhun gideceği yerin varlığına inanırlar. Halbuki bize göre kişinin cennet ve cehennemi bu dünyada. Ölümden sonra ruh, berzah denilen Tanrı'nın katına yükselir.

16- Bizim kavayani dediğimiz bayrağımız ve bestelediğimiz marşımız var. Zerdüştîler ikisine de sahip değildirler.

17- İnancımızda hayatın kaynağı Güneş’in büyük bir önemi vardır. Fakat Zerdüştiler bizim kadar Güneş’e değer vermezler.

18- Zerdüştîlerin kutsal görüp ziyaret ettiği yerler var. Biz de Kızkapan'1 kutsal görmekteyiz. Her y1l Peyman

mabetlerinde ateş, mabedin ortasında etrafı camla kaplı özel bir odada havana benzeyen adı âferingan/âprigun olan bir aracın içinde yanar. Bu ateșe Behrâm denilir. Sıradan bir Zerdüștînin bu ateșle direk temas kurması yasak olduğundan özel beyaz kıyafetlerini giymiş, ağzını da bir bezle kapatmış din adamı/môbed sadece ateşle temas kurabilir. Din adamları sırayla mabette nöbet tutarak odunla ateșin sürekli yanmasını sağlarlar. Zerdüştîlere göre bu, yıldırımın çakması neticesinde ortaya çıkmıș ve çok eski tarihlerden beri hiç sönmemiș/söndürülmemiș ateșin devamıdır (Bkz. Şehzâdî, 1380/2001: 75). 
Bayramımızı cemaat şeklinde def eşliğinde burada kutlarız.

Pîr Lokman bölgedeki Hıristiyan, Yahudi, Yezidi ve Ehl-i Hak/Kakai gibi dini azınlıklarla ilişkilerinin gayet iyi olduğunu, birbirine gelip gittiklerini söyler. O, Yezidi ve Ehl-i Hak'ın kültür, gelenek ve göreneklerini milli değerlere yakın gördüğünden onlara özel ilgisi olduğunu açıkça söylemektedir.

Hareketin şu an kendisine ait bir mezarlığı yoktur. Pîr Loman cemaatlerinden ölen birisinin Müslümanlarla aynı yere defin edilmesini büyük bir talihsizlik olduğunu fakat yapabilecekleri bir şey olmadığını belirtir (Pîr Lokman, Görüşme, 30/08/2019).

\section{Sonuç}

20. yüzyılın başından itibaren seküler milliyetçi Kürt aydınlar, Zerdüştîlik'e ilgi göstermeye başlamışlardır. Bir etnik-ulus yaratma amacında olan bu aydınlar, Kürtlerin Medlerden geldiklerini, İslam'dan önce dinlerinin Zerdüştîlik olduğunu iddia etmişlerdir. İddialar zamanla bir kısım okur-yazardan da karşılık bulmuştur. Yarı özerk Kuzey Irak'ta ortaya çıkan ilgi, kadîm köklerinden arınık, seküler ve milliyetçi yeni bir Zerdüştî Hareket'e dönüşmüştür. Hareket, yönetimdeki partiler tarafından da destek görmüştür.

Hatıraları zihinlerde hala canlı olan Saddam Hüsey'in Bölge'de yaptığı Enfal ve Halepçe katliamları ile 2014 yılında DEAŞ'ın düzenlediği saldırılar, Hareket'in Arapİslam karşıtı bir çizgide ilerlemesini sağlamıştır. Bölgesel Hükümet tarafından resmi olarak tanınması onu meşru bir zemine oturtmuş ve insanların Hareket'e bakışını olumlu yönde etkilemiştir.

Dini bir referansla ortaya çıkan Hareket, kadın-erkek eşitliği, sekülerizm, pozitivizm, demokrasi ve milliyetçilik gibi batılı değerlere atıf yapmaktadır. Ortadoğu'da ortaya çıkmış ve bu coğrafyaya ait dini bir geleneğe dayanmasına rağmen daha çok batıya yakın durmakta ve onu örnek almaktadır. Hareket'in içinde olanlar genelde Zerdüştîliği dinden öte kültürel bir kimlik olarak görmektedirler.

Halkın genelinin Müslüman ve geleneksel dini değerlere bağlı olduğu Kuzey Irak'ta, Hareket'in insanlardan yeterli ilgi gördüğü ve olumlu tepkiler aldığı söylenemez. Aksine olumsuz dönütler daha fazla olmaktadır. Bu noktada Hareket bir kesim entelijansiyanın teveccüh ettiği halktan kopuk bir görünüm arz etmektedir. Yakın gelecekte Bölge insanın geleceğinde söz sahibi olacak bir potansiyeli de barındırmamaktadır.

Çok değişken bir siyasi gündeme sahip Bölge'de, uzun vadede Hareket'in nasıl boyut kazanacağını tahmin etmek zordur. İktidarda pragmatik bir siyaset yürüten partiler, halktan gelen tepkilerle desteğini çekmesi hatta yasak getirmesiyle Hareket aniden popülaritesini kaybedebilir. Yönetime İslamc1 bir partinin gelmesi de durumu değiştirecek başka bir etkendir. Çünkü İslam'ın Bölge halkı üzerinde günümüzde olduğu gibi gelecekte de ana belirleyici unsur olmaya devam edeceği söylenebilir.

\section{Kaynakça}

Âferin, M. (1393/2014). Yezişn. Tahran: Neşr-i Fraveher.

Alalu, S. vd. (2001). Yahudilikte Kavram ve Değerler. İstanbul: Gözlem Gazetecilik Basın ve Yayın A.Ş. 2.

Aydın, M. (2005). Ansiklopedik Dinler Sözlüğü. Konya: Nüve Kültür Merkezi.

Aziz, M. A. (2013). Irak Kürtleri. Zülal Kılıç (Çev.). İstanbul: Kitap Yayınları.

Barber, M. T. (2019). Kurdish Zoroastrians: An Emerging Minority in Iraq. İçinde: Bayar M S. \& $\mathrm{T}$. Schmidinger (Ed), Beyond Ists: History and Future of Religious Minorities In Irak (229-235). London: Transnational Press London.

Bedirhan, K. A. (1932). Ferhengok. Hawar, 1(4), 33-42.

Bilgin, M. S. (2003). Zarathuştra. İstanbul: Berfin Yayınları.

Bruinessen, M. V. (1991). Religion in Kurdistan. Kurdish Times, 4(1-2) 5-27.

Cemilpaşa, E. (2018). Muhtasar Kürdistan Tarihi. İstanbul: Avesta Yayınları.

Filiz, İ. (2019). Siyasal Partiler Bağlamında Seküler Aktörler ve Íslamcı Aktörlerin İslam Algısı (Irak Kürt Bölgesi Örneği). Doktora Tezi. Ankara: Ankara Üniversitesi Sosyal Bilimler Enstitüsü.

Foltz, R. (Ocak 2017). The 'Original' Kurdish Religion?, Journal of Persianate Studies, 10(1), 87-104.

Galletti, M. (2016). Kürdistan Hiristiyanlarl. Heval Bucak (Çev.). İstanbul: Avesta Yayınları.

Guest, J. S. (2007). Yezidilerin Tarihi. İbrahim Bingöl (Çev.). İstanbul: Avesta Yayınları.

Guillemin, J. D. (1385/2006). Din-i Iran-ı Bastân. Rüya Müneccim (Çev.). Tahran: Neşr-i Ali.

Göle, N. (2017). Seküler ve Dinsel: Aşınan Sınırlar. İstanbul: Metis Yayınları.

Hanna, R. \& Barber, M. (2017). Erasing Assyrians: How ther KRG Abuses Human Rights, Undermines Democrarcy, and Conquers Minority Homelands. Belgium: Assyrian Confederation of Europe.

Herodotos. (2013). Herodotos Tarihi. Müntekim Ökmen (Çev). İstanbul: Türkiye İş Bankası Yayınları.

Hurşîdyan, E. (1387/2008). Cihanbîni-yi Eşû Zertoşt. Tahran: İntişârat-1 Fraveher.

Lescot, R. (2009). Yezidiler. Ayşe Meral (Çev.). İstanbul: Avesta Yayınları.

Moayyerî, H. (1381/2002). Muğân der Tarih-i Bastân. Tahran: Pejûheşgâh-1 Ulûm-1 İnsanî û Mutâlât-1 Ferhengî.

Nîknâm, K. (1388/2009). Âyîn-i İhtiyâr. Tahran: İntişârat-1 Tîs. 
Smith, C. M.I. \& Shadarevian, V. The Hopes And Fears Of Religlous Minorities In Northern Iraq. USCIRF, 2016

https://www.justice.gov/eoir/page/file/1265226/dow nload

Sular, M E. (2019). Modern İran'da Zerdüştîler. Ankara: Eski Yeni Yayınları.

Suvari, Ç. C. (2013). Ezidiler. Ankara: Ütopya Yayınları.

Szanto, E. (Mart-2018). Zoroaster was a Kurd: NeoZoroastrianism among the Iraqi Kurds. Iran and the Caucasus, (22) 96-110.

Şehzâdî, R. (1380/2001). Mecmû'a-l Sohenrânîhâ-yı Môbed-i Môbedân Rustem Şehzâdî. Mihrengîz Şehzâdî (Thk.). Tahran: Sazmân-1 Çâp-1 Hevâcı.

Xemgin, E. (2011). Aleviliğin Kökenindeki Mazda İnancı ve Zerdüsst Öğretisi. İstanbul: Berfin Yayınları.

\section{Internet Kaynakları}

IRNA, "İslamic Republic News Agency".

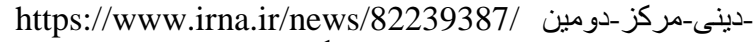
(22/09/2016). يافت_كثايش-عر اق-در-زرتشتيان,

KRG, "Kurdistan Regional Government". http://previous.cabinet.gov.krd/p/page.aspx?1=12\&s $=050000 \& r=304 \& p=214(09 / 11 / 2019)$.

WZO, "The World Zoroastrian Organisation". https://www.facebook.com/123200471075239/posts/ kurdish-zoroastrian-fire-temple-in-swedenkurdsopen-zoroastrian-temple-insweden/357967260903006/ (28/02/2012).

\section{ALBAYAN,}

http://www.albayan.co.uk/Article2.aspx?id=4963 $(12 / 12 / 2019)$.
ALBAYAN,

https://www.almonitor.com/pulse/ru/originals/2016/ 02/iraq-kurdistan-religious-minoritieszoroastrianism.html (17/07/2016).

$\mathrm{KP}$, $(19 / 11 / 2019)$.

$\mathrm{AO}$ "Atlas Obscura", https://www.atlasobscura.com/places/qyzqapantomb, (29/11/2019).

$\mathrm{RG}$,

"Religionguide", https://religionsguide.wordpress.com/2012/06/09/inv igning-av-zoroastriskt-tempel/ (09/01/2012).

FEZANA, "Federation of Zoroastrian Associations of North America".

https://www.fezana.org/files/Demographics/Zworld6 Sep12.pdf (01/02/2021).

\section{Katılımcı Kişiler}

-Cemal Husameddin (Gerçek isim, yaş 55, erkek) üniversite mezunu, ticaretle uğraşmakta.

-Muhammed Hamit Süleymani, (Gerçek isim, yaş 70, erkek), üniversite mezunu, emekli.

-Pîr Lokman, (Gerçek isim, yaş 51, erkek) üniversite mezunu.

-Azad, (Gerçek isim, yaş 45, erkek) lise mezunu.

-İbrahim, (Müster isim, yaş 50, erkek) üniversite mezunu.

-Awat Husameddin, (Gerçek isim, yaş 50, kadın) üniversite mezunu.

-Esaam, (Gerçek isim, yaş 52, erkek) lise mezunu.

-Diyako, (Gerçek isim, yaş 23, erkek) üniversite öğrencisi 


\section{Extended Abstract}

It seems that there have been some recent attempts to revive Zoroastrianism. We also encounter many concepts and symbols of this religion such as Avesta, Zoroaster and Fraveher as a person or institution name in social life. And besides this, the books of Zoroastrianism attract great attention. In addition, by establishing a connection between Kurds and Zoroastrianism, it was stated that the Kurds were Zoroastrian before Islam, that Zoroaster was a Kurdish prophet who lived in the Med State (728-559 BC), that his name comes from the Kurdish language, and similar allegations are frequently mentioned in some written sources. These allegations are made particularly by Kurdish nationalist secular intellectuals.

In fact, the origins of the secular nationalist Kurdish intellectuals' interest in Zoroastrianism actually dates back to the early 20th century. In this period, intellectuals such as Celadet and Kamuran Ali Bedirkhan claimed that the Kurds came from the Medes and that their pre-Islamic religion was Zoroastrianism. These allegations aimed to create a glorious history and an ancient religion for the Kurds, depending on the developing Kurdish nationalism. These alleged discourses have also found response among some literate groups over time as a result of this, the person named Andaz Hawezi founded a Zoroastrian temple in Stockholm, Sweden in 2012 with the supporters who were newly engaged in Zoroastrianism. With his support and those who returned from abroad, dynamism started in the transition to Zoroastrianism in Northern Iraq. The attacks of DAESH/ISIS in 2014 accelerated these transitions even more and a new Zoroastrian Movement emerged. The Movement, which took shape in the city of Sulaymaniyah, is officially represented by a woman named Awat Husamadin (known as Awat) in the Ministry of Evkaf (equivalent to the Presidency of Religious Affairs), where religious affairs are carried out by the Regional Government. This Movement, which started its activities in a single center in 2015, today continues its activities in separate centers in Süleymaniye as two groups with the names Yasna and Pir Luqman. It should also be noted that the two groups are not in friendly relations with each other.

In the field study, definited data could not be reached on the number of those who converted to Zoroastrianism and those who were in the Movement. Awat, who was asked about the subject, stated that their number exceeded hundreds of thousands by avoiding giving a clear number, and that every day, women and men Muslims, Christians, Arabs and Yazidis from different age groups joined them with a ceremony, and pointed out there were many people who concealed that they had converted to religion. Pir Luqman also gave a close answer by saying that dozens of people come to them every day. It can be said that the representatives of the both groups are in an effort to overestimate their numbers and the numbers given are exaggerated. Government officials also state that they do not have an exact number for those who entered Zoroastrianism in the region, but they mention numerical values expressed in hundreds. As a result, if it is necessary to give numbers, it can be said that the Movement consists of people to be expressed in hundreds. There is an interest in the Movement, especially from the literate people segment of the Region, who live in different places and are in communication. But it cannot be said that interest has reached great numbers by turning into participation.

Although the general of the region does not perform Islamic rituals such as five daily prayers and fasting, their belief is strong; They obey religious orders on matters such as clothing, food, drink and circumcision Therefore, it cannot be said that the Muslim people in Sulaymaniyah support or even know about the new Zoroastrian Movement.The Islamic communities in the region, on the other hand, do not consider conversion of religion, especially transition to Zoroastrianism, as a positive situation. From time to time, Islamic clerics and Islamic opinion leaders emerge who expressing their individual reactions to the Movement. This situation bothers and oppresses those who have converted to Zoroastrianism. In 2016, Salafi-minded Mullah Abd Latif Ahmad called for the condemnation of those who converted to Zoroastrianism. Pir Luqman interpreted this call as a sign of their own murder and stated that they were worried about religious radicalism. It is felt that there are problems and tension in public relations in interviews with people from both groups. However, it can be stated that the Movement has received political and financial support from the KDP and PUK, which are the parties in the Regional Government. The reason for this can be said to be the aim of the Region to move away from a political Islamic structure and gain a secular, nationalist character.

When asked how their relations with the Zoroastrians in Iran and India (those in India are called Parsi), Awat and Pir Luqman said that there was no problem between them, they had a good relationship, they came together in congresses and similar activities. However, they state that they do not exchange information on religious matters, and that those in India are Persian/Persian Zoroastrians and they are Zoroastrians of the Med State. Pir Luqman, who was educated by Zoroastrian clergy in Iran-India, states that there are nearly twenty differences between them and Persian Zoroastrians. The physical structure of the places used as sacred fire temple/ Atashkadeh in the two centers, the way of dress of the clergy, and the difference in the way some religious ceremonies are performed, confirm that the Zoroastrianism here is very different from the ancient Persian Zoroastrianism. The new religious understanding of both groups presents an artificial appearance devoid of historical background, religious law rules and scriptures. It is only three basic moral rules of good thought, good word and good deed, borrowed from Zoroastrianism. Although it is called Zoroastrianism, it can be stated that what is said and done in the name of religion has a political, nationalist, modern, liberal and artificial appearance.

In the Region, which has a very volatile political agenda, it is difficult to predict what kind of dimension the Movement will gain in the long run. The Movement may suddenly lose its popularity when the parties that carry out a pragmatic policy in power withdraw their support with the reactions from the public and even impose a ban. The coming of an Islamist party to power is another factor that will change the situation. Because it is not difficult to predict that Islam will continue to be the main determining factor on the people of the Region in the future as it is today. 